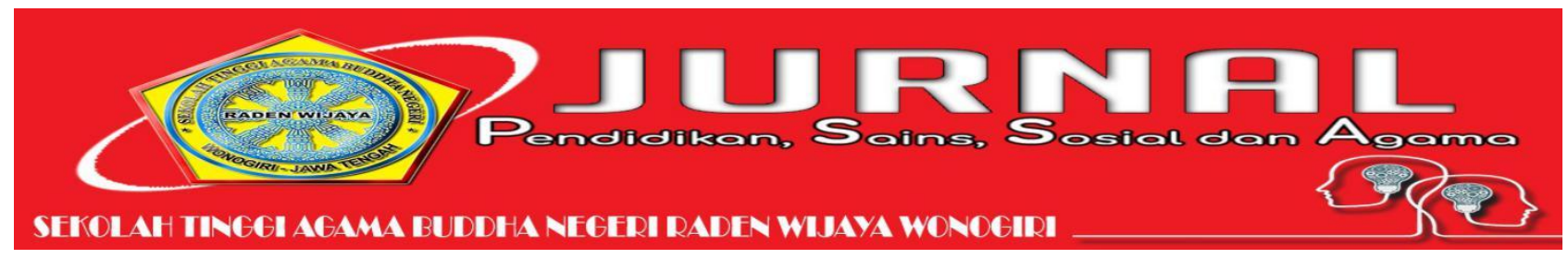

\title{
ANALISIS KESULITAN PEMBELAJARAN MATEMATIKA DENGAN SISTEM DARING MASA PANDEMI COVID-19 PADA SISWA KELAS VII DAN KELAS VIII SMP TAHFIZH AL-ITTIBA' KLATEN TAHUN AJARAN 2020/2021
}

\author{
Alfian Angga Putra1, Herry Agus Susanto², Djatmiko Hidajat ${ }^{3}$ \\ Universitas Veteran Bangun Nusantara Sukoharjo
}

fianfutra@gmail.com, herrysanto_62@yahoo.co.id,djatmikohidajat@gmail.com

\begin{abstract}
Abstrak
Tujuan penelitian ini untuk mendeskripsikan kesulitan pembelajaran matematika dengan sistem daring masa pandemi covid-19. Hasil penelitian diharapkan dapat dijadikan sebagai bahan pertimbangan untuk pengambilan keputusan dalam penanganan kesulitan belajar siswa. Penelitian ini menggunakan metode deskripstif dengan pendekatan kualitatif. Subjek pada penelitian ini adalah Siswa Kelas VII dan VIII SMP TAHFIZH AL-ITTIBA' Klaten pada semester genap tahun 2020/2021. Teknik pengumpulan data yang digunakan pada penelitian ini berupa angket dan wawancara. Hasil penelitian menunjukkan bahwa faktor internal penyebab kesulitan belajar meliputi aspek minat dengan persentase 60,60\% dalam kategori menghambat, aspek kesiapan belajar dengan presentasi 70,38 dalam kategori cukup menghambat, aspek motivasi dengan persentase 60,33\% dalam kategori menghambat, aspek kesehatan dengan persentase $82,88 \%$ dalam kategori tidak menghambat. Faktor eksternal penyebab kesulitan belajar meliputi aspek keluarga dengan persentase $86,14 \%$ dalam kategori tidak menghambat, aspek sekolah dengan persentase $62,93 \%$ dalam kategori cukup menghambat, dan aspek lingkungan atau masyarakat dengan persentase 66,30\% dalam kategori cukup menghambat.
\end{abstract}

Kata Kunci: Kesulitan Belajar, Pembelajaran Daring, Covid-19

\begin{abstract}
The purpose of this study is to describe the difficulties of learning mathematics with an online system during the covid-19 pandemic. The results of this study are expected to be used as input and consideration for decision making in the context of handling learning difficulties experienced by students. This study uses a descriptive method with a qualitative approach. The subjects in this study were Class VII and Class VIII SMP TAHFIZH AL-ITTIBA' Klaten in the even semester of the 2020/2021 academic year. Data collection techniques used in this study were in the form of questionnaires and interviews. The results showed that the difficulty of learning mathematics with an online system was influenced by internal factors and external factors. Internal factors that cause learning difficulties include aspects of interest with a percentage of $60.60 \%$ in the inhibiting category, aspects of learning readiness with a presentation of 70.38 in the moderately inhibiting category, motivational aspects with a percentage of $60.33 \%$ in the inhibiting category, health aspects with a percentage of $82.88 \%$ in the non-inhibiting category. External factors causing learning difficulties include family aspects with a percentage of $86.14 \%$ in the noninhibiting category, school aspects with a percentage of $62.93 \%$ in the moderately inhibiting category, and environmental or community aspects with a percentage of $66.30 \%$ in the moderately inhibiting category.
\end{abstract}

Keywords: Learning Difficulties, Online Learning, Covid-19 


\section{PENDAHULUAN}

Covid-19 salah satu penyakit yang dapat menular biasanya disebabkan oleh sindrom pernapasan akut coronavirus 2 (Severe Acute Respiratory Syndrome coronavirus 2 atau SARS-CoV-2). Virus ini tergolong keluarga besar Coronavirus yang dapat menyerang hewan. Ketika menyerang manusia, coronavirus biasanya menyebabkan penyakit infeksi saluran pernafasan, seperti flu, MERS, dan SARS (Setiawan, 2020: 29).

Presiden Jokowi menyampaikan prioritas dalam mencegah penyebaran virus corona covid-19 lebih luas lagi sangat penting untuk dilakukan, dengan mengurangi mobilitas orang dari satu tempat ke tempat yang lain. Demi tetap menjaga dunia pendidikan bisa tetap berjalan dengan baik serta mendukung Pemerintah dalam mendukung Psysical distanting ditengah Pendemi Covid-19 sesuai intruksi presiden untuk tetap dirumah, belajar dirumah, bekerja dirumah, ibadah dirumah. Menteri Pendidikan dan Kebudayaan (Mendikbud) menindak lanjuti kebijakan tersebut melalui Surat Edaran (SE) Nomor, 4 Tahun 2020 Tentang Pelaksanaan Kebijakan Pendidikan Dalam Masa Darurat Penyebaran Covid-19, dalam hal ini poin 2 yang menyatakan, proses Belajar dari Rumah dilaksanakan dengan ketentuan sebagai berikut: (a) Belajar dari Rumah melalui pembelajaran daring/jarak jauh dilaksanakan untuk memberikan pengalaman belajar yang bermakna bagi siswa, tanpa terbebani tuntutan menuntaskan seluruh capaian kurikulum untuk kenaikan kelas maupun kelulusan. (b) Belajar dari Rumah dapat difokuskan pada pendidikan kecakapan hidup antara lain mengenai pandemi Covid-19. (c) Aktivitas dan tugas pembelajaran Belajar dari Rumah dapat bervariasi antarsiswa, sesuai minat dan kondisi masing-masing, termasuk mempertimbangkan kesenjangan akses/ fasilitas belajar di rumah. (d) Bukti atau produk aktivitas Belajar dari Rumah diberi umpan baiik yang bersifat kualitatif dan berguna dari guru, tanpa diharuskan memberi skor/nilai kuantitatif.

\section{SMP TAHFIZH AL-ITTIBA'}

KLATEN menetapkan bahwa kegiatan belajar mengajar tatap muka ditiadakan. Salah satu mata pembelajaran matematika yang menerapkan dengan melakukan pembelajaran dalam jaringan (daring) atau online learning dari rumah masing - masing. Pembelajaran daring biasanya dikenal dengan e-learning, pembelajaran virtual, pembelajaran dengan mediasi komputer, pembelajaran berbasis web, dan pembelajaran jarak jauh. Semua istilah itu menyiratkan bahwa pelajar dan pengajar berada dalam lokasi yang berbeda, menggunakan media teknologi digital (biasanya komputer) untuk mengakses materi pelajaran dan berkomunikasi dengan dosen dan teman kapan saja mereka bisa (Nizam, 2020: 52).Belajar daring (online) dapat menggunakan teknologi digital seperti google classroom, rumah belajar, zoom, video converence, telepon atau live chat dan lainnya (Dewi, 2020: 58). Pemanfatan teknologi informasi diharapkan mampu mengatasi proses belajar mengajar bisa tetap berjalan dengan baik meskipun tengah berada masa pendemi Virus Corona Covid-19 (Pakpahan,2020: 31).

Matematika merupakan mata pelajaran yang wajib di dipelajari oleh siswa SMP TAHFIZH AL-ITTIBA' KLATEN .Pelajaran matematika merupakan salah satu pelajaran yang dipelajari siswa mulai dari sekolah dasar sampai perguruan tinggi.Menurut Frengky pelajaran matematika untuk pertama kali diterima secara formal oleh pengajar pada waktu mereka duduk di bangku kelas 1 sekolah dasar (SD).Dalam kehidupan seharihari siswa dihadapkan dengan masalah yang berkaitan dengan penerapan matematika. Penguasaan matematika yang baik akan dapat membantu menyelesaikan masalah tersebut. Untuk memahami suatu pokok bahasan matematika tentunya siswa terlebih dahulu harus menguasai konsep-konsep matematika (Mansur, 2018: 140). Menurut Andrew Noyes Matematika adalah suatu ilmupengetahuan yang menjadi bagian dari kehidupan manusia. Menurut Ruseffendi Matematika adalah ilmu tentang struktur yang terorganisasikan, Matematika membahas fakta-fakta dan hubungan-hubungan, serta membahas ruang dan bentuk.Pada intinya Matematika merupakan ilmu pengetahuan yang selalu terhubung dengan kehidupan manusia.Matematika juga membahas faktafakta, hubungan, serta ruang dan bentuk (Indah, 2017: 1). 
Berdasarkan survei kepada siswa SMP yang mengikuti pembelajaran matematika pada masa pandemi diperoleh hasil bahwa dari 72siswa yang menanggapi survei tersebut, siswa menyatan pembelajaran dengan sistem daring hanya menggunakan plat form WA dan Zoom, 95,5\% siswa menyatakan Saat darurat Covid-19, pembelajaran matematika di berikan secara daring, 56,9\% siswa merasa kurang memadai kepemilikan kouta yang digunakan untuk mengikuti pembelajaran matematika dengan sistem daring, 80,6\% siswa menyatakan Sinyal internet menjadi salah satu kendala saat mengikuti pembelajaran matematika dengan sistem daring, $72,2 \%$ siswa mentakan kurang tertarik anda mengikuti pembelajaran matematika dengan sistem daring, 72,2\% siswa menyatakan Pembelajaran dengan sistem daring kurang membantu untuk memahami materi yang didapatkan, 65,3\% siswa menyatakan sulit memusatkan perhatian ketika Pembelajaran daring dengan memanfaatkan platform digital (WA, Google Clasroom,Zoom, dil), 58,3\% siswamenyatakan bahwa guru ketika menyampaikan materi pembelajaran kurang jelas.

Berdasarkan penelitian yang dilakukan oleh Menueut Subini (2015: 13), Kesulitan belajar merupakan suatu kondisi dimana kompetensi atau prestasi yang dicapai tidak sesuai dengan kriteria standar yang telah ditetapkan, baik berbentuk sikap, pengetahuan, maupun keterampilan.Kesulitan belajar yang dimaksud disini adalah ketika pesertadidik tidak mampu mencapai kriteria ketuntasan minimal baik dalam segi sikap, pengetahuan, dan keterampilan.Menurut Mukhtar dan Rusmini (Nisa, 2017: 5) Kesulitan belajar adalah suatu kejadian atau peristiwa yang menunjukkan bahwa mencapai tujuan pembelajaran yang telah ditetapkan, ada sejumlah pesertadidik yang mengalami kesulitan dalam menguasai secara tuntas bahan atau materi pelajaran yang diberikan.Menurut Dalyono (Kumalasari dan Sugiman, 2015: 18), kesulitan belajar identik dengan kesukaran peserta didik dalam menerima atau menyerap pelajaran di sekolah.

\section{METODE}

Penelitian ini merupakan jenis penelitian deskriptif kualitatif. Menurut Creswell (Walidin, 2015: 75) mengemukakan bahwa penelitian kualitatif merupakan suatu proses penelitian untuk memahami masalah masalah manusia atau sosial dengan menciptakan gambaran menyeluruh dan kompleks yang disajikan dengan kata - kata, melaporkan pandangan terinci yang diperoleh dari para sumber informasi, serta dilakukan dalam latar (setting) yang alamiah. Subjek penelitian dilakukan dengan teknik purporsive sampling yaitu teknik pengambilan sampel sumber data dengan pertimbangan tertentu (Sugiono dalam Wulandari, 2020: 57). Pertimbangan dalam penelitian ini adalah sebagai berikut: a) Siswa kelas VII dan kelas VIII SMP TAHFIZH ALITTIBA' Klaten Tahun Ajaran 2020/2021 yang mengikuti perkuliahan online dengan Pembelajaran Daring.

Teknik pengumpulan data merupakan cara-cara yang dilakukan peneliti untuk mengumpulkan data yang mendukung tercapainya tujuan penelitian. Teknik pengumpulan data pada penelitian ini dengan cara kuisoner dan wawancara. Metode pengumpulan data yang digunakan untuk mengumpulkan data adalah metode angket berupa kuesioner.Kuesioner adalah metode pengumpulan data yang dilakukan dengan cara memberi seperangkat pertanyaan atau pernyataan tertulis kepada responden untuk dijawab menurut Sugiyono( Ambari, 2017: 719). Adapun kisi-kisi kesulitan belajar yang akan digunakan pada penelitian ini adalah sebagai berikut:

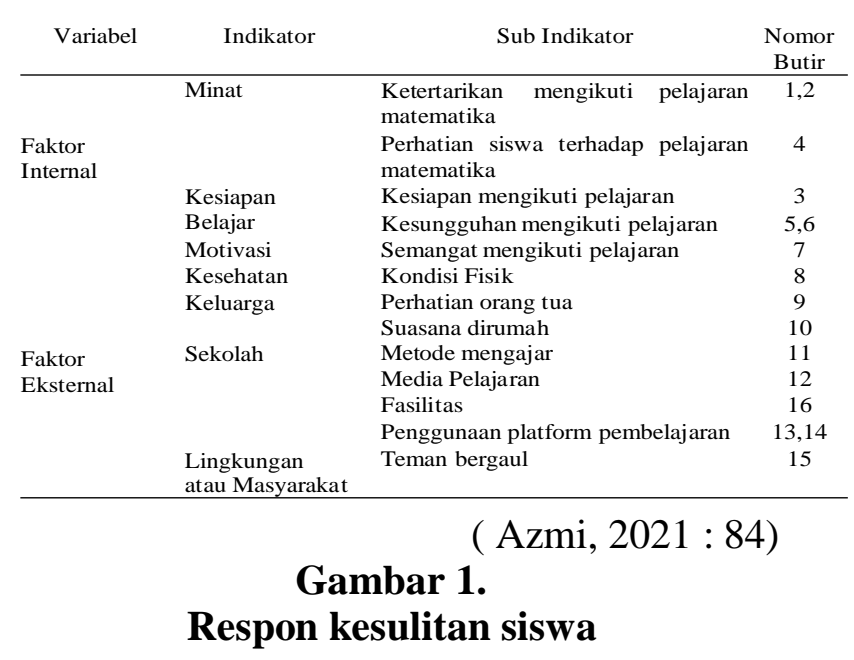


Teknik wawancara adalah proses memperoleh keterangan untuk tujuan penelitian dengan cara tanya jawab dengan mengajukan pertanyaan-pertanyaan terstruktur sambil bertatap muka antara pewawancara dengan informan, dengan menggunakan pedoman wawancara secara sistematis dan lengkap untuk mengumpulkan data yang dicari( Zuraeva, 2020: 41 ). Teknik pengambilan sampel wawancara pada penelitian ini menggunakan teknik purporsive sampling yaitu teknik pengambilan sampel sumber data dengan pertimbangan tertentu (Sugiono dalam Wulandari, 2020: 57), purposive sampling adalah teknik pengambilan sampel sebagai sumber data dengan pertimbangan tertentu. Berikut pedoman wawancara terhadap siswa .

\begin{tabular}{lll}
\hline Variabel & Indikator & Sub Indikator \\
\hline & Minat & Ketertarikan mengikutipelajaran matematika \\
& & Perhatian siswa terhadap pelajaran matematika \\
Faktor & Kesiapan Belajar & Kesiapan mengikuti pelajaran \\
Internal & & Kesungguhan mengikuti pelajaran \\
& Motivasi & Semangat mengikuti pelajaran \\
& Kesehatan & Kondisis Fisik \\
& Keluarga & Perhatian orang tua \\
& & Suasana dirumah \\
Faktor & Sekolah & Metode mengajar \\
Eksternal & & Media Pelajaran \\
& & Fasilitas \\
& & Penggunaan platform pembelajaran \\
& & Lingkungan ataul \\
& Teman bergaul \\
\hline
\end{tabular}

( Azmi, $2021: 84$ )

Gambar 2.

Pedoman wawancara

Prosedur analisis data dalam penelitian ini adalah reduksi data, penyajian data, dan penarikan simpulan/verifikasi.

Teknik analisis data dilakukan berdasarkan data yang diperoleh. Data yang digunakan dalam penelitian ini berupa angket dan wawancara. Wawancara ditujukan siswa yang telah menerapkan Sistem Pembelajaran Daring dan angket ditujukan kepada siswa untuk mengetahui respon mahasiswa terhadap proses dan kendala pemebelajaran di masa pandemicovid-19. Data yang diperoleh kemudian digunakan untuk menarik kesimpulan dari penelitian ini.

Angket respon siswa terdiri dari 7 indikator kesulitan pemebelajaran di masa pandemicovid-19.Angket yang diberikan menggunakan skala likert agar mendapatkan jawaban yang tegas terhadap pernyataan yang diberikan.

Memeriksa dan menghitung skor dari setiap jawaban yang dipilih oleh responden pada angket yang telah diberikan dengan pedoman penskoran berikut ini:

\begin{tabular}{lll}
\hline \multirow{2}{*}{ Pernyataan } & \multicolumn{2}{c}{ Skor Pernyataan } \\
\cline { 2 - 3 } & Positif & Negatif \\
\hline Sangat Setuju (SS) & 4 & 1 \\
Setuju (S) & 3 & 2 \\
Tidak Setuju (TS) & 2 & 3 \\
Sangat Tidak Setuju (STS) & 1 & 4 \\
\hline
\end{tabular}

\section{Gambar 3. \\ Penilaian skala}

Kemudian nilai dari respon siswa dihitung dan dianalisa dengan rumus berikut menurut Sugiono( dalam Mandasari, 2020: 275):

Persentase $(\%)=\frac{\text { Skoryangdiperoleh }}{\text { Jumlahseluruhskor }} \times 100$

Melakukan interpretasi hasil perhitungan persentase faktor-faktor penyebab kesulitan belajar tiap indikator. Pada penelitian ini menggunakan kriteria interpretasi skala sebagai berikut (Tamba, dkk., 2020: 82):

$$
\begin{array}{ll}
81,25 \%<\text { skor } \leq 100 \% & =\text { Tidak Menghambat } \\
62,50 \%<\text { skor } \leq 81,25 \% & =\text { Cukup Menghambat } \\
43,75 \%<\text { skor } \leq 62,50 \% & =\text { Menghambat } \\
25 \%<\text { skor } \leq 43,75 \% & =\text { Sangat Menghambat }
\end{array}
$$

Dalam memperoleh keakuratan dalam penelitian, penelitian ini menggunakan teknik triangulasi. Menurut Sugiono Triangulasiadalahprosesmenemukankesimpul an dari berbagai sudut pandang dengan upaya mengumpulkan

datadariberbagaisumberyangberbedadeanmen ggunakanmetodeyangbervariasi (Pratiwi, 2017: 213). Penelitian ini menggunakan triangulasi teknik. 


\section{HASIL DAN PEMBAHASAN}

Penelitian ini dilakukan pada tanggal 7 Juni 2021 kepada siswa kelas VII dan kelas VIII SMP TAHFIZH AL-ITTIBA' Klaten. Permasalahan yang diteliti pada penelitian ini berkaitan dengan faktor- faktor yang menyebabkan kesulitan belajar siswa ketika mengikuti pembelajaran matematika dengan sistem daring.Teknik analisis data dilakukan berdasarkan data yang diperoleh. Data yang digunakan dalam penelitian ini berupa angket dan wawancara yang dilakukan dengan memanfaatkan aplikasi WhatsApp (Video Call ). Angket kesulitan belajar digunakan untuk sumber data yang akan dianalisis datanya. Hasil dari angket kesulitan belajar sangat penting datanya karena berisi tentang faktorfaktor yang menyebabkan kesulitan belajar selama mengikuti pembelajaran matematika dengan sistem daring.Berikut hasil angket kesulitan belajar diberikan melalui platform Google Form yang telah dibagikan pada tanggal 8-11 Juni 2021 dan diisi oleh 92 mahasiswa.Berikut ini rangkuman hasil angket kesulitan pembelajaran matematika dengan sistem daring masa pandemi covid-19 pada siswa kelas VII dan kelas VIII SMP TAHFIZH AL-ITTIBA' Klaten Tahun Ajaran 2020/2021pada setiap aspek faktor-faktor kesulitanbelajar.

\begin{tabular}{|c|c|c|c|c|c|c|}
\hline No & Variabel & Indikator & $\begin{array}{c}\text { Skor } \\
\text { Perolehan }\end{array}$ & $\begin{array}{c}\text { Skor } \\
\text { Maksimal }\end{array}$ & $\begin{array}{c}\text { present } \\
\text { ase }\end{array}$ & Kategori \\
\hline \multirow[t]{4}{*}{1.} & Faktor & Minat & 669 & 1104 & $60,60 \%$ & Menghambat \\
\hline & Internal & $\begin{array}{l}\text { Kesiapan } \\
\text { Belajar }\end{array}$ & 777 & 1104 & $70,38 \%$ & $\begin{array}{c}\text { Cukup } \\
\text { Menghambat }\end{array}$ \\
\hline & & Motivasi & 222 & 368 & $60,33 \%$ & Menghambat \\
\hline & & Kesehatan & 305 & 368 & $82,88 \%$ & $\begin{array}{c}\text { Tidak } \\
\text { Menghambat }\end{array}$ \\
\hline \multirow[t]{3}{*}{2.} & $\begin{array}{c}\text { Faktor } \\
\text { Eksterna }\end{array}$ & Keluarga & 634 & 736 & $86,14 \%$ & $\begin{array}{c}\text { Tidak } \\
\text { Menghambat }\end{array}$ \\
\hline & 1 & Sekolah & 1158 & 1840 & $62,93 \%$ & $\begin{array}{c}\text { Cukup } \\
\text { Menghambat }\end{array}$ \\
\hline & & $\begin{array}{l}\text { Lingkungan } \\
\text { atau Masyarakat }\end{array}$ & 244 & 368 & $66.30 \%$ & $\begin{array}{c}\text { Cukup } \\
\text { Menghambat }\end{array}$ \\
\hline
\end{tabular}

Gambar 4.

Hasil angket kesulitan belajar pada setiap aspek

Untuk mendapatkan informasi yang lebih mendalam mengenai kesulitan belajar.Penelitian ini pengecekan keabsahan data diperoleh dari perbandingan hasil angket respons siswa dan hasil wawancara kepada siswa. Analisis data angket respons mahasiswa dan analisis hasil wawancara sebagai berikut :

Tabel 1.

Perbandingan hasil angket dan wawancara

\begin{tabular}{|c|c|c|c|}
\hline $\begin{array}{l}\mathbf{N} \\
\mathbf{0}\end{array}$ & $\begin{array}{l}\text { Sub } \\
\text { Indikator }\end{array}$ & $\begin{array}{ll}\text { Analisis } & \text { Hasi } \\
\text { Angket } & \end{array}$ & $\begin{array}{l}\text { Deskripsi } \\
\text { Jawaban }\end{array}$ \\
\hline 1. & $\begin{array}{l}\text { Ketertari } \\
\text { kan } \\
\text { mengiku } \\
\text { ti } \\
\text { pelajara } \\
\text { nmatem } \\
\text { atika }\end{array}$ & $\begin{array}{l}\text { Persentase } \\
\text { hasil angket } \\
\text { pada aspek } \\
\text { minat sebesar } \\
59,51 \% \\
\text { sehingga } \\
\text { termasuk } \\
\text { pada kategori } \\
\text { menghambat } \\
\text { siswa dalam } \\
\text { belajar } \\
\text { matematika } \\
\text { dengan } \\
\text { sistemdaring. }\end{array}$ & $\begin{array}{l}\text { Dua siswa } \\
\text { tertarik } \\
\text { mengikuti } \\
\text { pembelajar } \\
\text { an dengan } \\
\text { sistem } \\
\text { daring } \\
\text { Tujuh } \\
\text { siswa tidak } \\
\text { tertarik } \\
\text { mengikuti } \\
\text { pembelajar } \\
\text { an dengan } \\
\text { sistem } \\
\text { daring } \\
\text { Dua siswa } \\
\text { cukup } \\
\text { tertarik } \\
\text { mengikuti } \\
\text { pembelajar } \\
\text { an dengan } \\
\text { sistem } \\
\text { daring }\end{array}$ \\
\hline 2. & $\begin{array}{l}\text { Ketertarik } \\
\text { an } \\
\text { mengikuti } \\
\text { pelajaran } \\
\text { matematik } \\
\text { a }\end{array}$ & $\begin{array}{l}\text { Persentase } \\
\text { hasil angket } \\
\text { pada aspek } \\
\text { minat sebesar } \\
52,99 \% \text { sehing } \\
\text { ga termasuk } \\
\text { pada kategori } \\
\text { menghambat } \\
\text { siswa dalam } \\
\text { belajar } \\
\text { matematika } \\
\text { dengan } \\
\text { sistemdaring. }\end{array}$ & $\begin{array}{l}\text { Enam } \\
\text { siswa } \\
\text { cukup } \\
\text { senang } \\
\text { mengikuti } \\
\text { pembelajar } \\
\text { andengan } \\
\text { sistem } \\
\text { daring } \\
\text { Lima siswa } \\
\text { tidaksenan } \\
\text { g } \\
\text { mengikuti } \\
\text { pembelajar } \\
\text { andengan } \\
\text { sistem } \\
\text { daring. }\end{array}$ \\
\hline
\end{tabular}




\begin{tabular}{|c|c|c|c|}
\hline 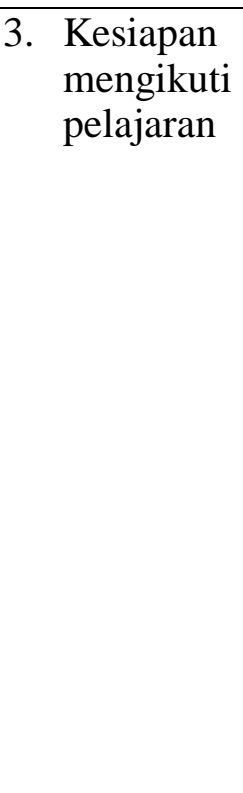 & $\begin{array}{l}\text { Persentase } \\
\text { hasil angket } \\
\text { pada aspek } \\
\text { kesiapan } \\
\text { belajar } \\
\text { sebesar } \\
78,26 \% \\
\text { sehingga } \\
\text { termasuk } \\
\text { pada kategori } \\
\text { cukup } \\
\text { menghambat } \\
\text { siswa dalam } \\
\text { belajar } \\
\text { matematika } \\
\text { dengan } \\
\text { sistemdaring. }\end{array}$ & $>$ & $\begin{array}{l}\text { Empat } \\
\text { siswa } \\
\text { belajar } \\
\text { terlebih } \\
\text { dahulu. } \\
\text { Tiga } \\
\text { siswakadan } \\
\text { g-kadang } \\
\text { belajar. } \\
\text { Empat } \\
\text { siswa tidak } \\
\text { belajar } \\
\text { terlebih } \\
\text { dahulu }\end{array}$ \\
\hline
\end{tabular}

4. Perhatian siswa terhadappe lajaranmat ematika

$\begin{array}{ll}\text { Persentase } & \text { Sembilan } \\ \text { hasil angket } & \text { siswa aktif } \\ \text { pada aspek } & \text { bertanya } \\ \text { minat sebesar } & \text { kepada } \\ 69,29 \% \text { sehing } & \text { guru ketika } \\ \text { ga termasuk } & \text { mengalami } \\ \text { pada kategori } & \text { kesulitan } \\ \text { cukupmengha } & \text { memahami } \\ \text { mbat siswa } & \text { materi } \\ \text { dalam belajar } & \text { yang } \\ \text { matematika } & \text { disampaika } \\ \text { dengan } & \text { n secara } \\ \text { sistemdaring. } & \text { daring } \\ & >\text { Dua siswa } \\ & \text { tidak aktif } \\ & \text { bertanya } \\ & \text { kepada } \\ & \text { guru ketika } \\ & \text { mengalami } \\ & \text { kesulitan } \\ & \text { memahami } \\ & \text { materi } \\ & \text { yang } \\ & \text { disampaika } \\ & \text { n secara } \\ & \text { daring }\end{array}$

5. Kesunggu Persentase $>$ Delapan hanmengi hasil angket siswameng kutipelajar pada aspek erjakan an

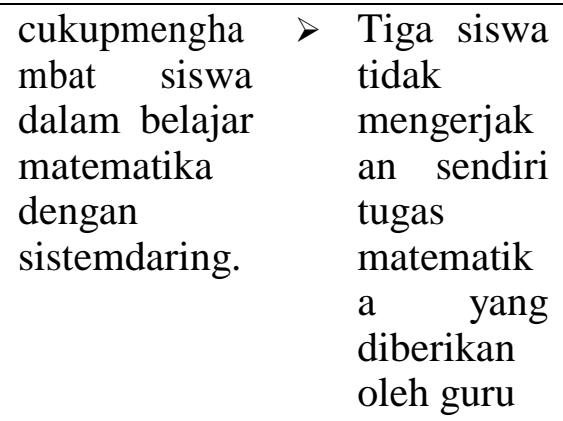

Tiga siswa tidak mengerjak an sendiri tugas matematik a yang diberikan oleh guru

Persentase

hasil angket pada aspek motivasi

sebesar

$60,33 \%$ sehing ga termasuk pada kategorimeng hambat siswa dalam belajar matematika dengan sistemdaring. materi yang di sampaikan guru.

\section{Empat} siswa tidak mempelajar i kembali materi yang di sampaikan guru.

\section{Tiga siswa} menyataka n gurumengg unakan metode pembelajar an yang bervariasi sehingga lebih mudah memahami materi yang diajarkan

\section{Delapan} siswa menyataka n guru tidak mengguna kan metode pembelajar 


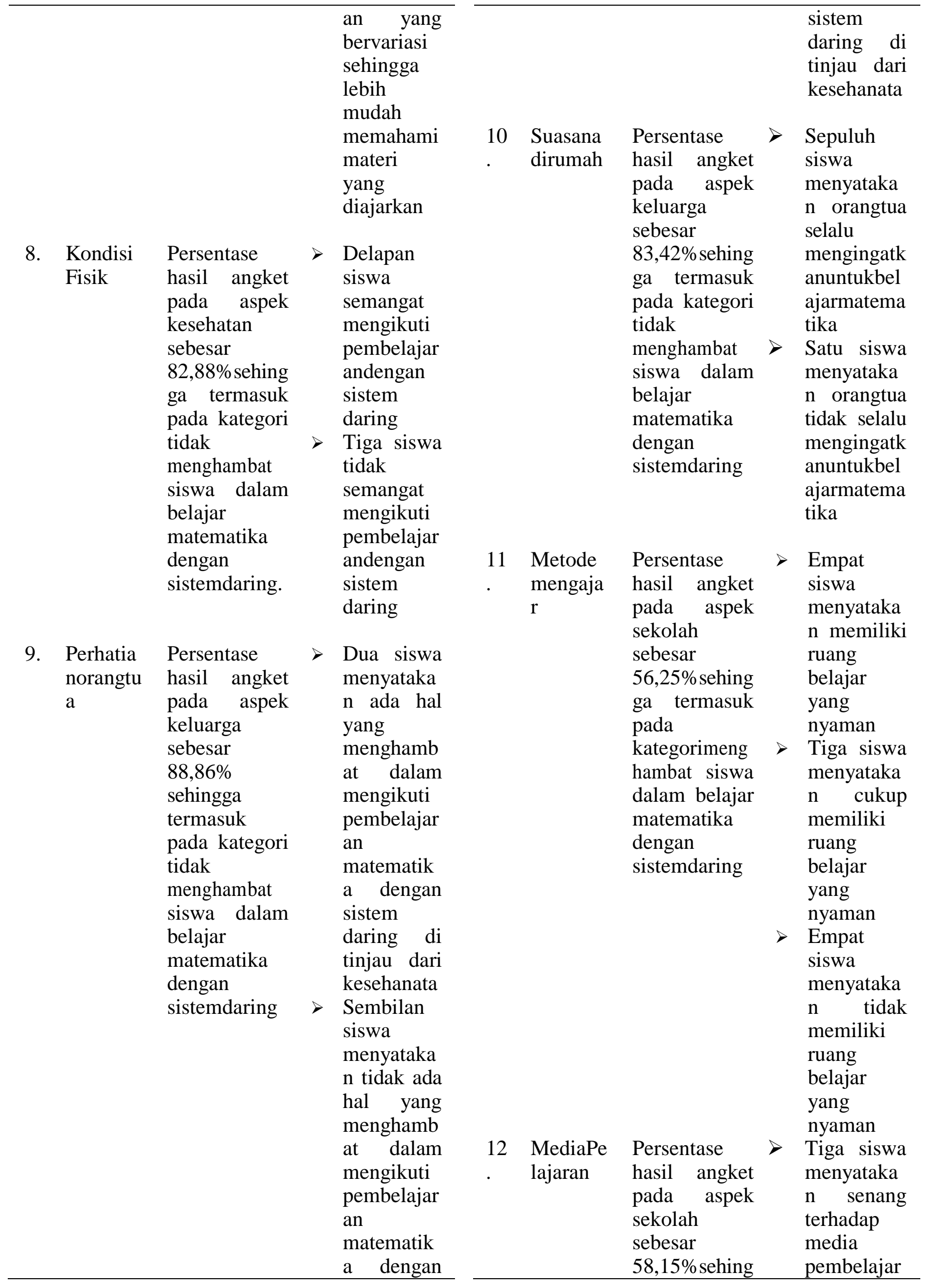




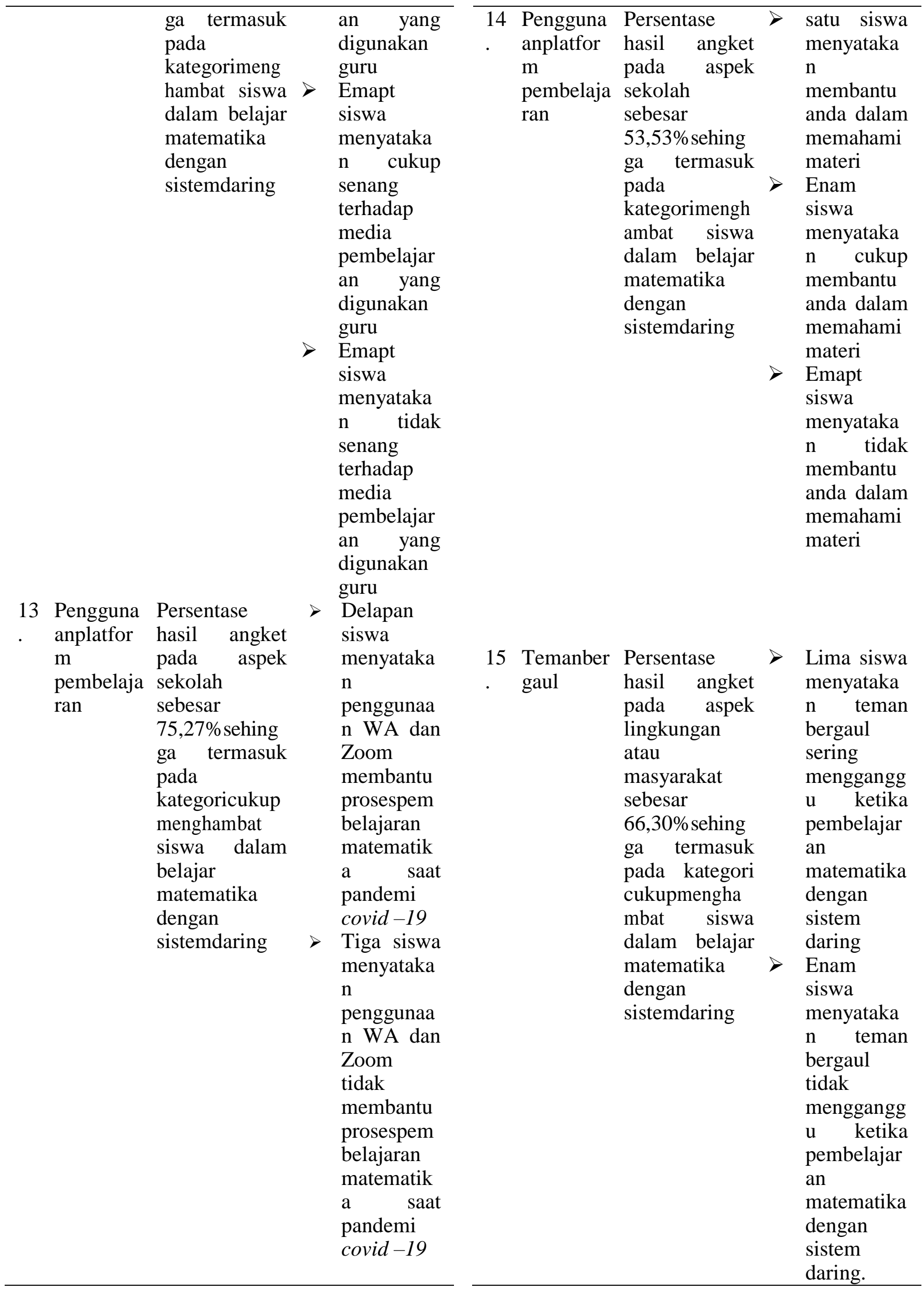




\begin{tabular}{cll}
\hline 16 Fasilitas & $\begin{array}{l}\text { Persentase hasil } \\
\text { angket pada } \\
\text { aspek sekolah } \\
\text { sebesar }\end{array}$ & $\begin{array}{l}\text { Enam } \\
\text { siswa } \\
\text { menyatan } \\
\text { mendapat }\end{array}$ \\
& $71,47 \%$ sehingga & bantuan \\
termasuk pada & subsidi \\
kategoricukup & kouta \\
menghambat $>$ & Lima siswa \\
siswa dalam & menyatan \\
belajar & tidak \\
matematika & mendapat \\
dengan & bantuan \\
& sistemdaring & subsidi \\
& kouta \\
\hline
\end{tabular}

Dari tabel di atas bahwa kBerdasarkan paparan hasil penelitian menunjukkan bahwa kesulitan belajar siswa pada pembelajaran matematika dengan sistem daringg disebabkan oleh faktor internal (dari dalam dirisiswa) dan faktor eksternal (dari luar diri siswa). Faktor interne; dan eksternal penyebab kesulitan belajar termasuk dalam kategori menghambat dan cukup menghambat Siswa Kelas VII dan Kelas VIII SMP TAHFIZH AL-ITTIBA' Klatendalam Pembelajaran Matematika dengan Sistem Daring Masa Pandemi Covid19. Oleh karena itu, perlu adanya upaya-upaya dalam rangka penanganan kesulitan belajar yang dialami siswa.

Untuk mengetahui lebih jelas mengenai kesulitan belajar Siswa Kelas VII dan Kelas VIII SMP TAHFIZH AL-ITTIBA' Klatendalam Pembelajaran Matematika dengan Sistem Daring, maka perlu dideskripsikan faktor- faktor yang menyebabkan terjadinya kesulitan belajar pada setiap aspek dan indikatornya. Berikut adalah pemaparan hasil penelitian terhadap faktorfaktor yang menyebabkan kesulitan belajar.

Faktor internal penyebab kesulitan belajar yang pertama yaitu aspek minat dengan persentase hasil angket sebesar $60,60 \%$ pada kategori menghambat siswa dalam pembelajaran matematika dengan sistem daring. Dari hasil wawancara menunjukkan bahwa siswa lebih tertarik jika pembelajaran dilakukan secara konvensional. Hal ini menunjukkan bahwa minat belajar siswa perlu ditingkatkan karena menurut rusmiati (2017: 21), bahwa minat belajar berpengaruh terhadap prestasi belaja siswa.

Faktor internal penyebab kesulitan belajar yang kedua yaitu aspek kesiapan belajar dengan persentase hasil angket sebesar $70.38 \%$ pada kategori cukup menghambat siswa dalam pembelajaran matematika dengan sistem daring. Hal ini menunjukkan bahwa kesulitan belajar motivasi belajarsiswa perlu ditingkatkan karena menurut SIRAIT ( 2017: 207 ) kesiapan belajar tinggi memberikan kontribusi yang lebih dominan dibandingkan gaya belajar visual dan auditorial dengan kesiapan belajar tinggi maupun rendah terhadap pemahaman konsep matematika.

Faktor internal penyebab kesulitan belajar yang ketiga yaitu aspek motifasi belajar dengan persentase hasil angket sebesar $60,33 \%$ pada kategori menghambat siswa dalam pembelajaran matematika dengan sistem daring. Hal ini menunjukkan bahwa motivasi belajarsiswa perlu ditingkatkan karena menurut Harianti dan Amin (2016: 25), motivasi merupakan faktor yang banyak berpengaruh terhadap proses dan hasil belajar dengan kontribusi sebesar $36 \%$ terhadap prestasi akademik. Siswa yang memiliki motivasi yang tinggi akan memiliki kreativitas ynag tinggi. Kreativitas dapat memungkinkan para siswa dan guru memecahkan berbagai permasalahan di kelas (Widodo, 2021).

Faktor internal penyebab kesulitan belajar yang keempat yaitu aspek kesehatan dengan persentase hasil angket sebesar $82,88 \%$ pada kategori tidak menghambat siswa dalam dalam pembelajaran matematika dengan sistem daring.

Faktor eksternal penyebab kesulitan belajar yang pertama yaitu aspek keluarga dengan persentase hasil angket sebesar $86,14 \%$ pada kategori tidak menghambat siswa siswa dalam pembelajaran matematika dengan sistem daring.

Faktor eksternal penyebab kesulitan belajar yang kedua yaitu aspek sekolah dengan persentase hasil angket sebesar $66,30 \%$ pada kategori cukup menghambat siswa dalam dalam pembelajaran matematika dengan sistem daring. Menurut Nurtanto (2016: 563), tenaga pendidik merupakan komponen penting dalam kegiatan belajar mengajar sehingga harus mempunyai kompetensi yaitu kompetensi secara akademik dan kemampuan keahlian yang mengacu pada kompetensi pedagogik, kepribadian, sosial, 
danprofessional.Halinimenunjukkanbahwastr ategipembelajaran dan media pendukung mempengaruhi hasil belajar yang dicapai siswa sehingga pemilihan strategi dan media pendukung harus benar- benar diperhatikan.

Faktor eksternal penyebab kesulitan belajar yang ketiga yaitu aspek lingkungan atau masyarakat dengan persentase hasil angket sebesar $66,30 \%$ pada kategori cukup menghambat siswa dalam dalam pembelajaran matematika dengan sistem daring Dari hasil wawancara menunjukkan bahwa dalam pembelajaran matematika dengan sistem daring siswa merasa tidak bisa fokus dalam belajar di karenakan lebih tergoda bermain dengan teman. Menurut Desiningrum, (2017: 46), dari kerucut pengalaman belajar, diketahui bahwa peserta didik akan mencapai hasil belajar $10 \%$ dari apa yang dibaca, 20\% dari apa yang didengar, $30 \%$ dari apa yang dilihat, $50 \%$ dari apa yang dilihat dan didengar, $70 \%$ dari apa yang dikatakan dan $90 \%$ dari apa yangdikatakandandilakukan.Halinimenunjukk anbahwastrategipembelajaran dan media pendukung mempengaruhi hasil belajar yang dicapai mahasiswa sehingga pemilihan strategi dan media pendukung harus benarbenar diperhatikan.

\section{KESIMPULAN}

Berdasarkan hasil penelitian dan pembahasan yang telah diuraikan, maka dapat diambil kesimpulan bahwa kesulitan belajar Siswa Kelas VII dan Kelas VIII SMP TAHFIZH AL-ITTIBA' Klatendalam Pembelajaran Matematika dengan Sistem Daring Masa Pandemi Covid-19 disebabkan oleh faktor internal dan faktor eksternal kategori menghambat ( aspek minat dan aspek motifasi ),kategori cukup menghambat ( aspek kesiapan belajar, aspek sekolah, dan aspek lingkungan atau masyarakat ). Sehingga diperlukan upaya-upaya dalam rangka penanganan kesulitan belajar yang dialami olehsiswa agar tujuan pembelajaran dapat tercapai secara maksimal.

\section{DAFTAR PUSTAKA}

1. Azmi, Nur. 2021." Analisis Kesulitan Belajar Matematika pada Siswa SD Negeri 11Banda

SaktiLhokseumawe".
JurnalPendidikanMatematika.. Vol. 1 No. 2 Hal. 81-88.

2. Desiningrum, Noviana. 2017. "Implementasi Pendekatan Ketterampilan Proses, Konvensional dan Minat Belajar untuk Meningkatkan Prestasi Belajar". Jurnal Mitra Pendidikan. Vol. 1, No. 1, Maret 2017.

3. Harianti, Rini dan Suci Amin. 2016. "Pola Asuh Orang Tua dan Lingkungan Pembelajaran terhadap Motivasi Belajar Siswa". Jurnal Curricula.Vol. 1, No. 2, Hal.20-29.

4. Indah, L.Nur'aini.,Erwin Harahap., Farid H. Badruzzaman., dan Deni Darmawan. 2017." Pembelajaran Matematika Geometri Secara Realistis Dengan GeoGebra".Jurnal Matematika. Vol.16 No.2 Hal 1-6.

5. Kumalasari, Ade dan Sugiman. 2015. "Analisis Kesulitan Belajar Mahasiswa pada Mata Kuliah Kapita Selekta Matematika Sekolah Menengah". Jurnal Riset Pendidikan Matematika. Vol. 2, No. 1, Hal. 16-27

6. Mandasari, Lola., Elfi Rahmadhani., dan Septia Wahyuni. 2020." EFEKTIVITAS PERKULIAHAN DARING PADA MATA KULIAH ANALISIS KOMPLEKS SELAMA PANDEMI COVID 19.urnal As-Salam. Vol. 4 Mulyadi. 2008. "Diagnosis Kesulitan Belajar".Yogyakarta:Nuha Litera.

7. Nisa, Afiatin. 2017."PERANAN BIMBINGAN DAN KONSELING DALAM MEMBANTU MENGATASI MASALAH KESULITAN BELAJAR SISWA“. Jurnal Bimbingan dan Konseling. Vol. 1, No. 2,Hal.1-11.

8. Nizam. 2020. 21 Refleksi Pembelajaran Daring di Masa Darurat. Semarang: Universitas Katolik Soegijapranata.

9. Nurtanto, Muhammad. 2016. "Mengembangkan Kompetensi Profesionalisme Guru dalam Menyiapkan Pembelajaran yang Bermutu". Prosiding Seminar Nasional Inovasi Pendidikan. Hal. 553-565.

10. Pakpahan, R., dan Yuni, F. (2020). "Analisa Pemanfaatan Teknologi Informasi Dalam PembelajaranJarak Jauh Di Tengah Pandemi Virus Corona Covid19 ". JISAMAR Vol. 4 No. 2 Hal. 30-36. 
11. Pratiwi, Nuning Indah. 2017. "Penggunaan Media Video Call dalam Teknologi Komunikasi". Jurnal Ilmiah Dinamika Sosial. Vol. 1 No. 2 Hal. 202 - 224.

12. Rusmiati. 2017. “ PENGARUH MINAT BELAJAR TERHADAP PRESTASI BELAJAR BIDANG STUDI EKONOMI SISWA MA AL FATTAH SUMBERMULYO". Jurnal Ilmiah Pendidikan dan Ekonomi. Vol. 1 No. 1 Hal 21-36.

13. Setiawan, A. R. (2020). "Lembar Kegiatan Literasi Saintifik untuk Pembelajaran Jarak Jauh Topik Penyakit Coronavirus 2019 (Covid-19)". Jurnal Ilmu Pendidikan. Vol. 2 No. 1 Hal. $28-37$

14. Sirait, Erlando doni. 2017. "PENGARUH GAYA DAN KESIAPAN BELAJAR TERHADAP PEMAHAMAN KONSEP MATEMATIKA SISWA". Jurnal Formatif. Vol. 7 No. 3 Hal 207-218

15. Subini, Nini. 2015.”Mengatasi Kesulitan Belajar pada Anak". Yogyakarta: Javalitera

16. Tamba, Yusnita Renata, Martina Asiati Napitupulu dan Merry Sidabukke. 2020. "Analisis Kesulitan Belajar Siswa pada Materi Hewan Invertebrata di Kelas X". Jurnal Pelita Pendidikan. Vol. 8, No. 1, Hal. 80-88.

17. Walidin, Warul. 2015. Metodologi Penelitian Kualitatif \& Grounded Theory. Banda Aceh: FTK Ar-Raniry Press.

18. Wulandari, Andhika Ayu dan Erika Laras Astutiningtyas. $2020 . \quad$ "Analisis Kemampuan Komunikasi Matematis Mahasiswa dalam Pembelajaran Relasi Rekurensi". Jurnal Math educator Nusantara. Vol. 6 No. 1 Hal. 54 - 64.

19. Widodo, U. (2021). Uji Signifikansi Pengaruh Kreativitas Belajar pada Keterampilan Membaca Siswa. Kajian Bahasa, Sastra Dan Pengajaran, 5(2), 95-106. https://doi.org/https://doi.org/10.31539/k ibasp.v5i1.2970 